\title{
Initial Growth and Gas Exchanges of Plants of Colored Cotton Submitted to Saline Stress
}

\section{Hallyson Oliveira*, Ronaldo do Nascimento, Samuel Silva, José Alberto Ferreira Cardoso, Rafaela Felix Basílio Guimarães, Elka Costa Santos Nascimento}

Post-Graduated of Agricultural Engineer, Federal University of Campina Grande, Campina Grande, Brazil

Email: *hallysonoliveira_@hotmail.com

How to cite this paper: Oliveira, H., do Nascimento, R., Silva, S., Cardoso, J.A.F., Guimarães, R.F.B. and Nascimento, E.C.S. (2018) Initial Growth and Gas Exchanges of Plants of Colored Cotton Submitted to Saline Stress. Agricultural Sciences, 9, 1652-1663.

https://doi.org/10.4236/as.2018.912115

Received: December 2, 2018

Accepted: December 26, 2018

Published: December 29, 2018

Copyright $\odot 2018$ by authors and Scientific Research Publishing Inc. This work is licensed under the Creative Commons Attribution International License (CC BY 4.0).

http://creativecommons.org/licenses/by/4.0/

\begin{abstract}
The objective of the research was to evaluate the effects of saline stress on the initial growth and physiological parameters of three varieties of cotton plants, being two cultivars of colored fiber (BRS Topázio and BRS Verde) and one of white fiber (BRS 286). The experiment was conducted under greenhouse conditions. After chemical depletion with sulfuric acid, five seeds were seeded in polyethylene pots of $20 \mathrm{~kg}$, leaving only one plant per pot after thinning. The experimental design was completely randomized, with a factorial scheme of $3 \times 5$, with five replications, totaling 75 plots, being three cotton varieties and five saline stress treatments-1.1; 3.1; $5.1 ; 7.1 ; 9.1 \mathrm{dS} \mathrm{m}^{-1}$. The evaluations occurred at 15 and 30 days after the beginning of the treatments (DAT) for growth variables (plant height, stem diameter, number of leaves and leaf area) and gas exchange (stomatal conductance, net photosynthesis rate and transpiration. The variety that was most resistant to the salt stress levels studied was BRS 286, followed by BRS Topazio and BRS Verde.
\end{abstract}

\section{Keywords}

Photosynthesis, Stomatal Conductance, Dry Mass, Resistance, Cultivars

\section{Introduction}

Salinity caused by the excessive concentration of salts in the soil solution, or even in the waters used for irrigation, is also considered an abiotic stress limiting the growth and production of plants [1]. High levels of salts in the soil solution reduce the capacity of water absorption by the roots, transport and use of the ions necessary for the growth and development of the plants [2].

Saline stress causes several physiological changes in the plant, such as reduction of leaf water potential, stomatal closure, reduction of photosynthetic rate, 
decrease of aerial part, acceleration of senescence, leaf abscission, among others [3]. Therefore, the stomatal closure also becomes a defense mechanism of the plants to avoid water loss and eventual death by desiccation [4]. However, the process of photosynthesis is impaired, because it depends directly on the stomatal opening, for the assimilation of the carbonic gas in its biochemical stage.

The reduction of water absorption by plants, due to excess salts in the soil solution, is one of the main factors that undermine the photosynthetic process. According to [5], when it happens, the stomatal conductance is reduced, in the influx of $\mathrm{CO}_{2}$ to the chloroplasts, and thus, the photosynthetic rate falls, also decreasing the transpiration.

The cotton crop is characterized as raw material of the agrotêxtil chain, being incorporated in about $90 \%$ of the total natural fibers consumed in Brazil. It is domesticated and cultivated in places where water deficiency is not necessarily an aggravating factor [6]. In addition, it is a culture considered to be tolerant to salinity [7].

Due to resistance to low rainfall and moderate levels of salinity, colored cotton has great importance in the semi-arid region. In addition, it is a crop used in the production of textiles due to the non-use of dyes or other chemical derivatives, thus adding more value to the finished product [8].

Therefore, this research had as objective to evaluate the initial growth, chlorophyll and the variables of gas exchange of different cotton cultivars, when submitted to saline stress.

\section{Material e Methods}

The research was carried out in a greenhouse, located at the Federal University of Campina Grande-PB, campus I, under the following geographic coordinates: $7^{\circ} 13^{\prime} 11^{\prime \prime S}$ and $35^{\circ} 52^{\prime} 31^{\prime \prime} \mathrm{W}$; altitude of $550 \mathrm{~m}$. The duration of the survey was two consecutive months (September and October 2016). Cotton cultivars were evaluated, being one of white fiber (BRS 286) and two of colored fiber (BRS topaz and BRS Verde).

Before sowing, the seeds were chemically demarcated using sulfuric acid in the proportion of $7 \mathrm{~kg}$ of seeds per liter of acid. After delignification, these seeds were washed with $5 \%$ sodium hydroxide $(\mathrm{NaOH})$ and water for the removal of linter and sulfuric acid residues. This process is necessary to prevent proliferation of fungi or other agents that may cause seed damage and subsequent germination.

For the distribution of the vessels in the experimental area, a completely randomized design was used, with a factorial scheme $3 \times 5$, with 5 replications, totaling 75 experimental plots. This factorial scheme is defined by three cotton cultivars (BRS Topázio, BRS Verde and BRS 286) and five different levels of electrical conductivity of water-1.1;3.1; $5.1 ; 7.1 ; 9.1 \mathrm{dS} \mathrm{m}^{-1}$.

Vessels with capacity of two liters were used, containing three holes in the base to allow drainage, and filled with $300 \mathrm{~g}$ of gravel to cover, subsequently, 
filled with $3.5 \mathrm{~kg}$ of soil, classified as Argiloso Franco Latosol.

Only foundation fertilization was carried out, incorporating in each vessel amounts of $0.77 \mathrm{~g}$ of urea, $5.83 \mathrm{~g}$ of single superphosphate and $0.90 \mathrm{~g}$ of potassium chloride, according to [9]. Then the soil was placed in field capacity, using water supply.

The water in use was stored in reservoirs of $100 \mathrm{~L}$. The different levels of salinity in water $(\mathrm{CEa})$ were obtained from the dissolution of sodium chloride in rainwater and water supply. These concentrations of $\mathrm{NaCl}$, to be diluted to determine the desired CEa, were found based on the equation of [10], described below.

$$
\text { Conc. } \mathrm{NaCl}=\frac{585 \times(C E d-C E u) \times V t}{1000}
$$

where: Conc. $\mathrm{NaCl}-$ Concentration of sodium chloride (g);

$C E d$-desired electrical conductivity $\left(\mathrm{dS} \mathrm{m}^{-1}\right)$;

$C E u-$ electrical conductivity of used water $\left(\mathrm{dS} \mathrm{m}^{-1}\right)$;

$V t$-Total reservoir volume (L).

Five cotton seeds were sown per experimental plot, filled with soil at a depth of $5 \mathrm{~cm}$. The emergence started 4 days after sowing (DAS), thinning at 10 DAS, leaving only one plant per pot. Soil scarification of the soil occurred before each irrigation and mentoring of some plants, in order to avoid tipping. In addition, there were applications of insecticides and fungicides when necessary.

Up to $10 \mathrm{DAS}$, irrigation was performed with moisture close to the field capacity, using only water supply. From then on, the irrigation occurred from two days in two days, always at 7 o'clock, applying in each vessel the appropriate treatment.

The evaluations occurred at 15 and 30 days after application of the treatments (DAT). The growth of the cotton cultivars was evaluated through the determination of plant height (AP), stem diameter (DC), number of leaves (NF) and leaf area (FA). The leaf area was determined by the equation proposed by [11], in leaves with length of main vein equal to or greater than $3 \mathrm{~cm}$ :

$$
Y=0.4322 X^{2.3002}
$$

where: $\mathrm{Y}=$ Leaf area, $\mathrm{cm}^{2} ; \mathrm{X}=$ Length of main vein of the leaf, $\mathrm{cm}$.

The gas exchange variables of the plants, involving the stomatal conductance (gs) $\left(\mathrm{mol} \mathrm{m}^{-2} \cdot \mathrm{s}^{-1}\right)$, net photosynthesis rate (A) $\left(\mu \mathrm{mol} \mathrm{m} \mathrm{m}^{-2} \cdot \mathrm{s}^{-1}\right)$ and transpiration (E) $\left(\mathrm{mmol} \mathrm{m} \mathrm{m}^{-2} \cdot \mathrm{s}^{-1}\right)$ were measured using the IRGA equipment, brand ADC, model LCpro-SD. These evaluations were carried out between 8 and 10 am, at 15 and $30 \mathrm{DAT}$. A source of artificial light was coupled to the apparatus in order to obtain a flux density of photosynthetic photons of $1200 \mu \mathrm{mol} \mathrm{m}{ }^{-2} \cdot \mathrm{s}^{-1}$.

At the end of the experiment, 45 DAS, the plants were removed from the vases, separating leaves, stem and root. After weighing the fresh mass of these materials, they were placed in a forced circulation oven at $65^{\circ} \mathrm{C}$ for 48 hours. After this period, there was a new weighing to obtain the dry mass of the different 
parts.

The results obtained from the evaluated variables were submitted to analysis of variance through the statistical software SISVAR. The means were compared by the Tukey test at $5 \%$ probability. In the cases of significance, regression analysis was performed [12].

\section{Results and Discussion}

As observed in Table 1, the increasing salinity levels affected significantly ( $\mathrm{p}<$ $5 \%)$ all the growth variables evaluated, at 15 and 30 days after application of the treatments (DAT).In relation to the factor genotype $(\mathrm{G})$ and interaction $(\mathrm{SxG})$, the only variable that did not have a significant effect ( $\mathrm{p}<5 \%$ ) was the stem diameter (DC) for the two periods analyzed (15 and 30 DAT).

The average results for $\mathrm{AP}, \mathrm{DC}, \mathrm{NF}$ and $\mathrm{AF}$, in the two evaluated periods, were adjusted to the linear regression model (Figure 1), indicating a reduction of these variables as a function of the increase of the salt level of the water applied to the soil. Probably, this was due to the reduction of water absorption by the roots of the plant, due to the accumulation of salts in the soil solution, which reduces its osmotic potential and, consequently, its water potential, making water absorption difficult.

At 15 DAT, the mean data of AP, DC, NF and AF decreased between the lowest $\left(1.1 \mathrm{dS} \mathrm{m}^{-1}\right)$ and the highest $\left(9.1 \mathrm{dS} \mathrm{m}^{-1}\right)$ saline level of $28.0 \%, 17.1 \%, 30.9 \%$ and $68.7 \%$, respectively, resulting in a reduction of $3.5 \%, 2.1 \%, 3.9 \%$ and $8.6 \%$, respectively. At $30 \mathrm{DAT}$, the linear trend of the mean results continued to decrease, but more sharply, being $39.3 \%$ for AP; $27.3 \%$ for DC; $57.5 \%$ for NF and $73.0 \%$ for $\mathrm{AF}$, with a decrease, by unit increase of CEa, sequentially, of $4.9 \%$, $3.4 \%, 7.2 \%$ and $9.1 \%$.

According to [13], the reduction of growth of the plants when submitted to salinity conditions may be related to lower water absorption due to the decrease of the osmotic potential of the soil solution. The decrease of the leaf area and the

Table 1. Summary of ANOVA with the p-values regarding plant height (AP), stem diameter (DC), number of leaves (NF) and leaf area (FA), in the periods of 15 and $30 \mathrm{DAT}$, of cotton plants submitted to different levels of salinity.

\begin{tabular}{cccccccccc}
\hline & & \multicolumn{7}{c}{ ANOVA-SALINE STRESS } \\
\cline { 3 - 10 } $\begin{array}{c}\text { VariationFa } \\
\text { ctor }\end{array}$ & GL & $\begin{array}{c}\text { AP-15 } \\
\mathrm{cm}\end{array}$ & $\begin{array}{c}\text { AP-30 } \\
\mathrm{cm}\end{array}$ & $\begin{array}{c}\text { DC-15 } \\
\mathrm{mm}\end{array}$ & $\begin{array}{c}\text { DC-30 } \\
\mathrm{mm}\end{array}$ & NF-15 & NF-30 & $\begin{array}{c}\text { AF-15 } \\
\mathrm{cm}^{2}\end{array}$ & $\begin{array}{c}\text { AF-30 } \\
\mathrm{cm}^{2}\end{array}$ \\
\hline Sal. (S) & 4 & $0.0000^{*}$ & $0.0000^{*}$ & $0.0000^{*}$ & $0.0000^{*}$ & $0.0000^{*}$ & $0.0000^{*}$ & $0.0000^{*}$ & $0.0000^{*}$ \\
Gen.(G) & 2 & $0.0000^{*}$ & $0.0053^{*}$ & $0.0661^{\mathrm{ns}}$ & $0.1308^{\mathrm{ns}}$ & $0.0000^{*}$ & $0.0000^{*}$ & $0.0000^{*}$ & $0.0000^{*}$ \\
S x G & 8 & $0.0327^{*}$ & $0.8229^{\mathrm{ns}}$ & $0.6981^{\mathrm{ns}}$ & $0.1478^{\mathrm{ns}}$ & $0.0017^{*}$ & $0.0281^{*}$ & $0.0081^{*}$ & $0.0049^{*}$ \\
CV (\%) & & 9.80 & 8.06 & 7.40 & 5.10 & 11.87 & 12.70 & 20.85 & 18.39 \\
\hline
\end{tabular}

ns: not significant; ${ }^{*} \mathrm{p}<5 \%$ by the Tukey test. 

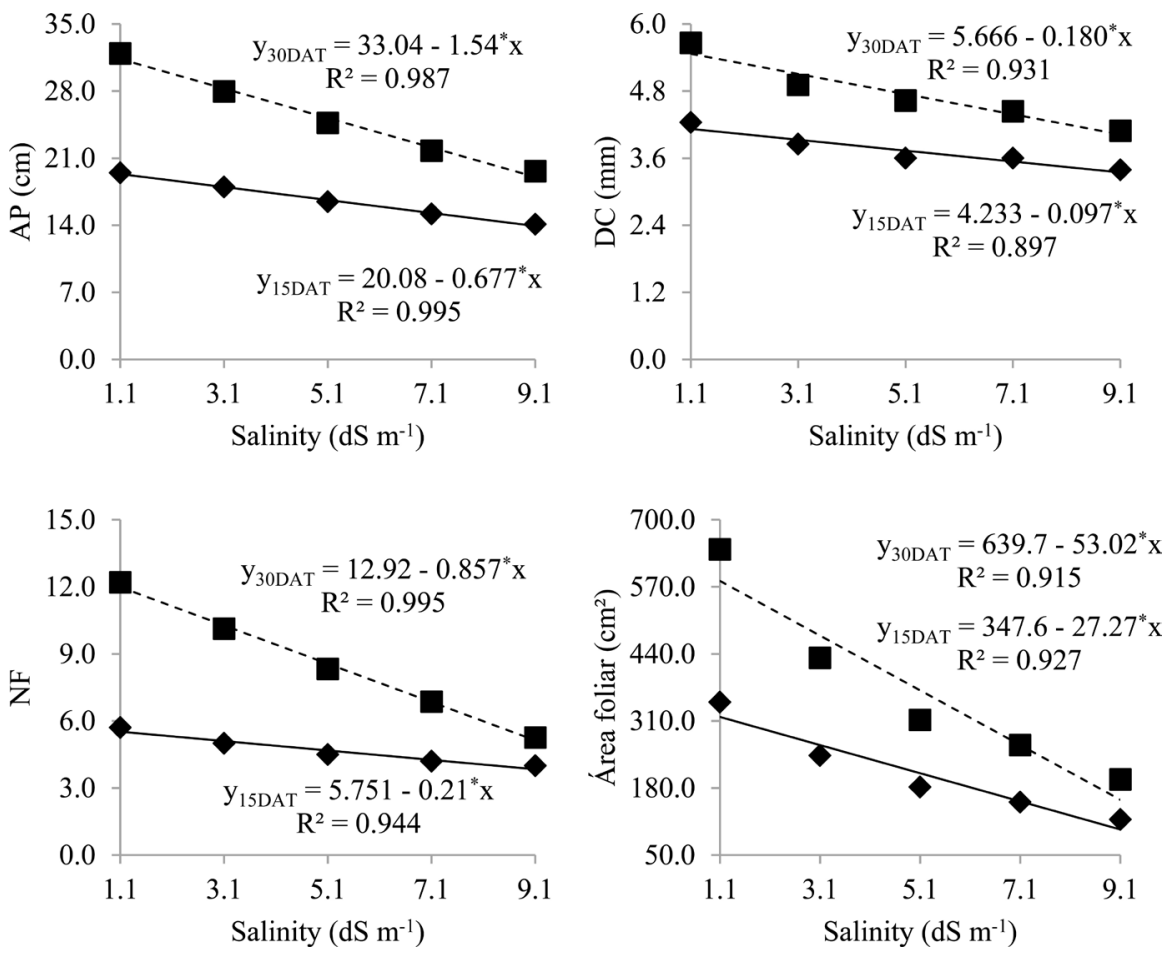

Figure 1. Plant height (AP), stem diameter (DC), number of leaves (NF) and leaf area (PA), as a function of increasing water salinity levels $\left(\mathrm{dS} \mathrm{m}^{-1}\right)$, at 15 and 30 days DAT.

number of leaves can show a physiological mechanism of adaptation of the plants to the saline stress, to avoid the loss of water by transpiration [14]. In addition, the decrease in leaf area may have occurred, possibly due to the reduction of the number of leaves, being this, a response of the plants to saline stress, aggravating during the time of this exposure.

Similar results were obtained by [15], which studied the morphology and production of BRS Topazio colored cotton, irrigated with saline waters, observed reductions in plant height, stem diameter and leaf area as a function of salinity increase.

According to Figure 2, the cultivar BRS Topázio differed significantly from BRS 286 in AP, suffering less damage to the growth, at the different levels of salts applied in the soil, at 15 DAT $(17.6 \mathrm{~cm})$ and 30 DAT $(26.3 \mathrm{~cm})$. In NF, these two cultivars were only statistically different from the $30 \mathrm{DAT}$, whereas in AF there was not significant distinction between them. This difference in growth between varieties of the same crop may be related to the better capacity of osmotic adaptation of genotypes, allowing a greater or lesser absorption of water in salinity conditions [16].

The BRS Verde obtained mean data significantly different from the others, in all growth variables, obtaining the lowest values. [17] observed in their studies with BRS Verde cotton that the effects of salinity were quite negative on initial growth, especially for plant height, number of leaves and leaf area.

Regarding the variables of fresh and dry mass (Table 2), it can be seen that 

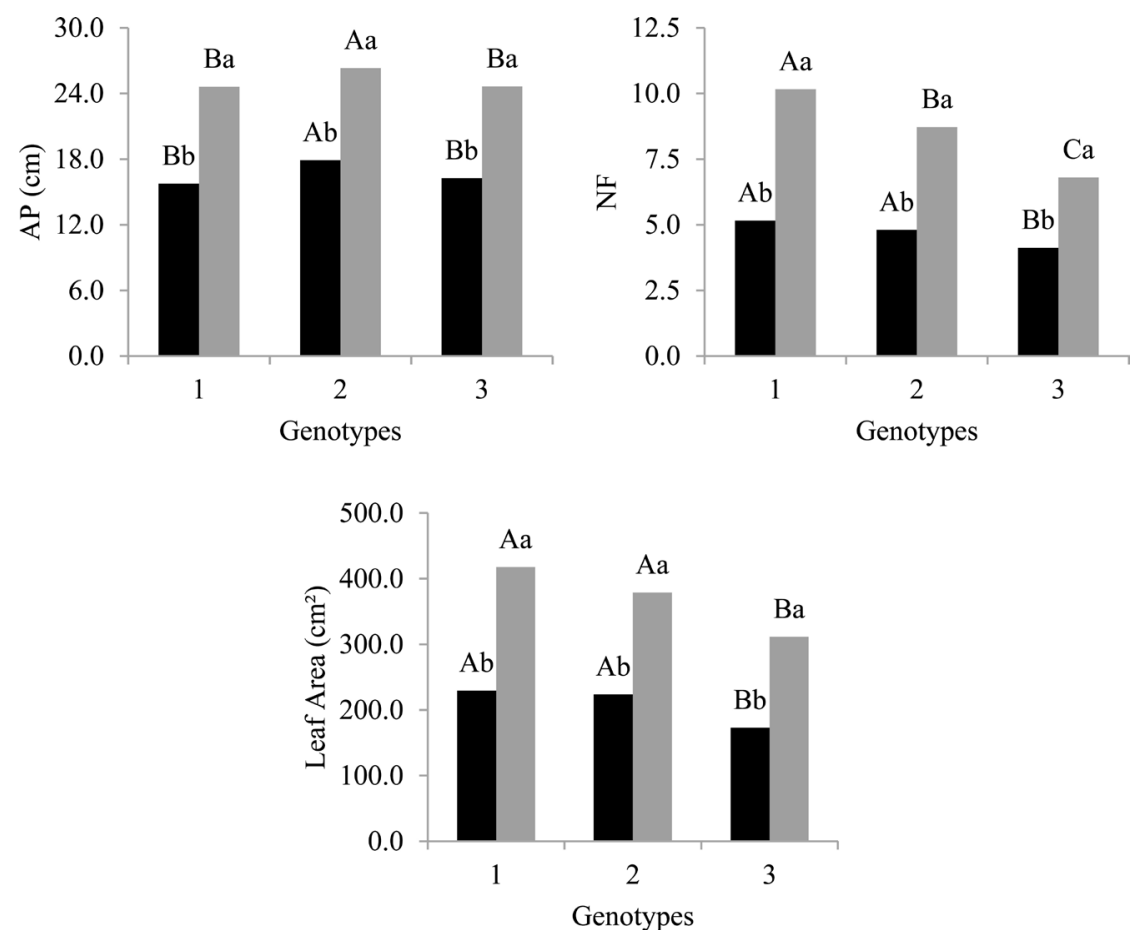

Figure 2. Plant height (AP), number of leaves (NF) and leaf area (AF) for the genotype factor. Equal capital letters do not differ between genotypes. Equal lowercase letters do not differ between times. 1-BRS 286; 2-BRS Topázio; 3-BRS Verde. - -Average values at 15 DAT; $\square-$ Average values at 30 DAT.

Table 2. Summary of ANOVA with the p-values of fresh masses of leaves, stem and roots (MFF, MFC, MFR) and dry masses of leaves, stem and roots (MSF, MSC, MSR) of cotton plants submitted to different salinity levels.

\begin{tabular}{cccccccc}
\hline & & \multicolumn{7}{c}{ ANOVA-SALINE STRESS } \\
\cline { 3 - 7 } VariationFactor & GL & MFF & MSF & MFC & MSC & MFR & MSR \\
\cline { 3 - 8 } & & & \multicolumn{7}{c}{ g } \\
Sal. (S) & 4 & $0.0000^{*}$ & $0.0000^{*}$ & $0.0000^{*}$ & $0.0000^{*}$ & $0.0000^{*}$ & $0.0000^{*}$ \\
Gen. (G) & 2 & $0.0000^{*}$ & $0.0000^{*}$ & $0.5499^{\text {ns }}$ & $0.0000^{*}$ & $0.0001^{*}$ & $0.0009^{*}$ \\
S x G & 8 & $0.0000^{*}$ & $0.0062^{*}$ & $0.0734^{\text {ns }}$ & $0.0025^{*}$ & $0.0090^{*}$ & $0.0043^{*}$ \\
CV (\%) & & 13.13 & 11.58 & 10.20 & 12.83 & 4.64 & 15.33 \\
\hline
\end{tabular}

ns: not significant; ${ }^{*} \mathrm{p}<5 \%$ by the Tukey test.

there was a significant effect of the isolated factor $\mathrm{S}$ for all these variables. The $\mathrm{G}$ factor and interaction $(S \times G)$ did not exert significance only in the fresh stem mass variable (MFC).

According to Figure 3, the average results obtained by the variables of fresh and dry masses of leaves, stem and roots were adjusted to the linear regression equation, occurring reduction of these variables, according to the increase of salts in the substrate. The highest increase of fresh and dry weight in leaves, stem and roots occurred at the salinity level of $1.1 \mathrm{dS} \mathrm{m}^{-1}$, and the lowest in the CEa of 

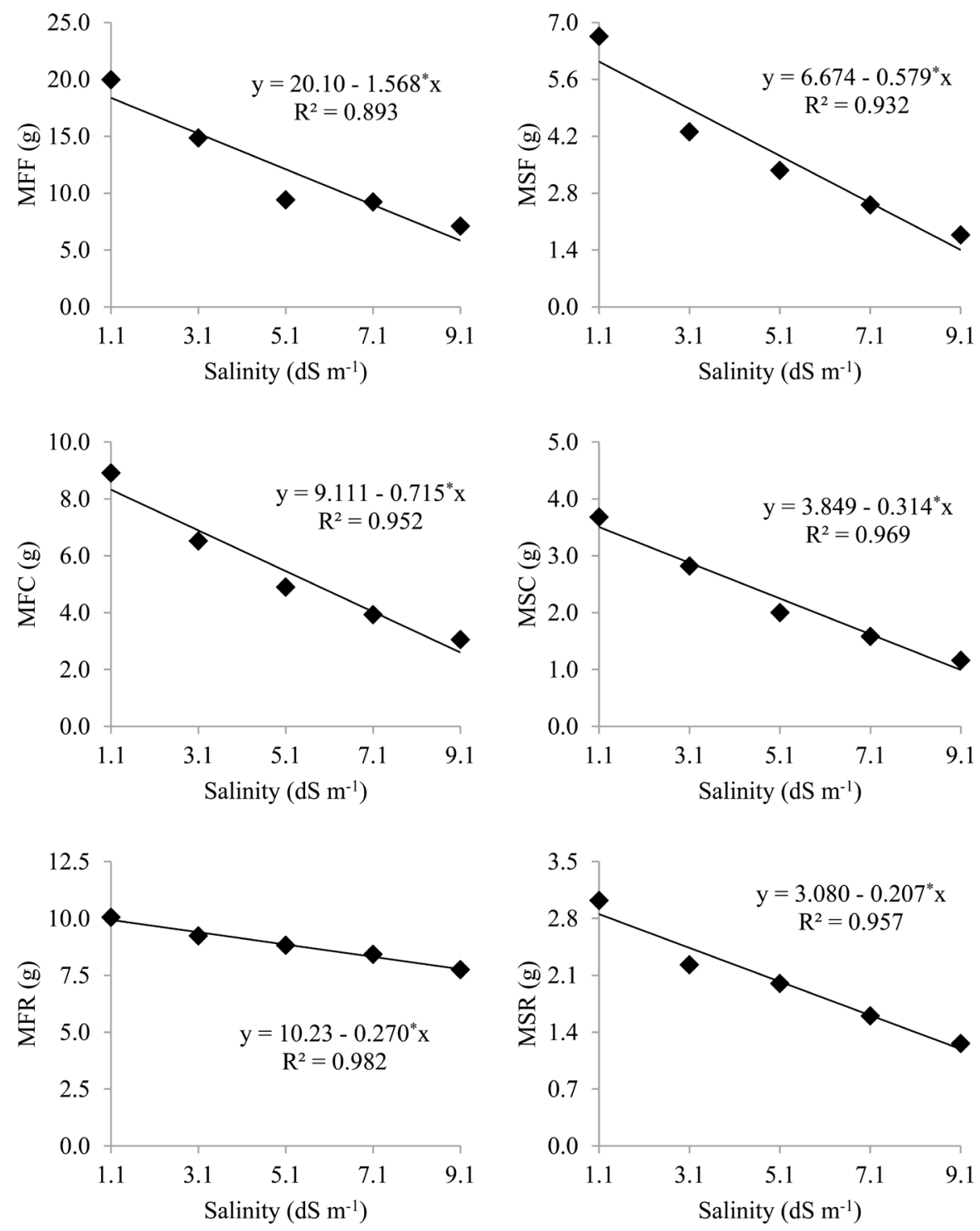

Figure 3. Fresh masses of leaves, stem and roots (MFF, MFC, MFR) and dry masses of leaves, stem and roots (MSF, MSC, MSR), as a function of increasing levels of CEa (dS $\left.\mathrm{m}^{-1}\right)$.

$9.1 \mathrm{dS} \mathrm{m} \mathrm{m}^{-1}$. This is probably due to the difficulty that plants have to absorb water in environments with low osmotic potential, which leads to less accumulation of mass.

This decrease of fresh and dry biomass of the different parts of the plant may also be related to the reduction of the leaf area, because for [18], the part of the plant most sensitive to high levels of salts is the leaf. According to [19], with the reduction of leaf area, several simultaneous processes of plant development are impaired, such as reduction of the photosynthetic process, water absorption and nutrients, affecting growth and, consequently, biomass production. [20], evaluating the initial growth of three cotton cultivars under saline stress, also observed a decrease in fresh and dry masses of leaves, stem and roots when the salt 
levels increased in irrigation water.

It is observed in Figure 4 that the white cotton cultivar, BRS 286, differed statistically from the other genotypes studied in all variables, obtaining better average results for MFF, MSF, MFR and MSR.

In relation to the gas exchange variables evaluated (Table 3), it can be observed at $15 \mathrm{DAT}$ that the $\mathrm{S}$ factor had a significant effect on all the gas exchange variables, except on the stomatal conductance (gs). At 30 DAT, the increasing salinity levels affected negatively all variables analyzed.

The $\mathrm{G}$ factor, on the other hand, only presented significance at $30 \mathrm{DAT}$, only in the mean data of stomatal conductance (gs) and transpiration (E). The
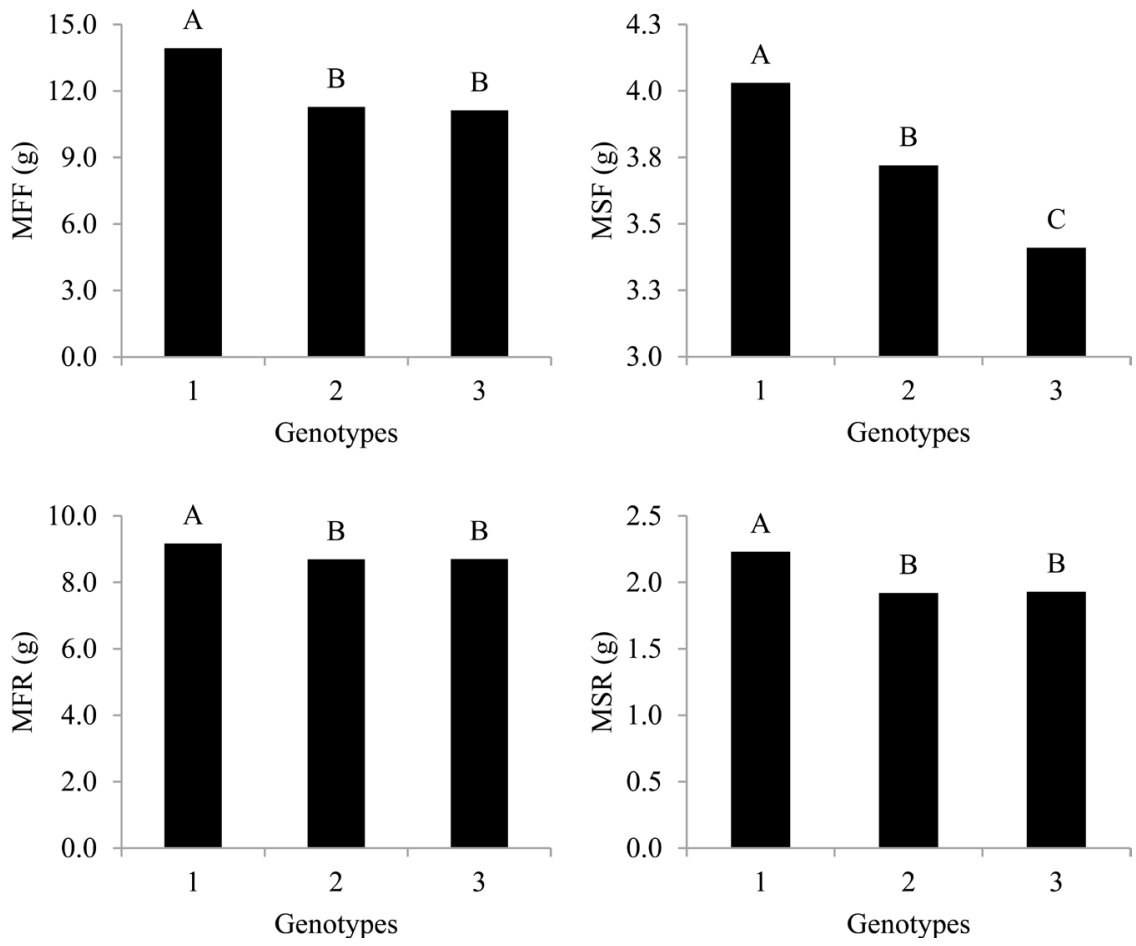

Figure 4. Fresh masses of leaves and roots (MFF, MFR) and dry masses of leaves and roots (MSF, MSR) for the genotype factor. Averages with the same letter do not differ significantly from each other. 1-BRS 286; 2-BRS Topázio; 3-BRS Verde.

Table 3. Summary of ANOVA with the p-values regarding stomatal conductance (gs), liquid photosynthesis rate (A) and transpiration (E) of cotton plants submitted to different levels of salinity.

\begin{tabular}{cccccccc}
\hline \multirow{2}{*}{ Variation Factor } & GL & \multicolumn{5}{c}{ ANOVA-SALINE STRESS } \\
\cline { 3 - 7 } & & gs-15 & gs-30 & A-15 & A-30 & E-15 & E-30 \\
\hline Sal. (S) & 4 & $0.8962^{\mathrm{ns}}$ & $0.0104^{*}$ & $0.0000^{*}$ & $0.0000^{*}$ & $0.0000^{*}$ & $0.0076^{*}$ \\
Gen. (G) & 2 & $0.7196^{\mathrm{ns}}$ & $0.0039^{*}$ & $0.3906^{\mathrm{ns}}$ & $0.3843^{\mathrm{ns}}$ & $0.1070^{\mathrm{ns}}$ & $0.0045^{*}$ \\
S x G & 8 & $0.1547^{\mathrm{ns}}$ & $0.3354^{\mathrm{ns}}$ & $0.1217^{\mathrm{ns}}$ & $0.5951^{\mathrm{ns}}$ & $0.7011^{\mathrm{ns}}$ & $0.7157^{\mathrm{ns}}$ \\
CV (\%) & & 30.23 & 32.39 & 7.41 & 11.29 & 10.66 & 23.36 \\
\hline
\end{tabular}

ns: not significant; ${ }^{*} \mathrm{p}<5 \%$ by the Tukey test. 
interaction $(S \times G)$ did not present a significant effect on the gas exchange variables studied.

At $30 \mathrm{DAT}$, the stomatal conductance (gs) of the cotton cultivars presented a linear decrease, with the increase of saline levels (Figure 5(a)), obtaining a reduction, between CEa of 1.1 and $9.1 \mathrm{dS} \mathrm{m}^{-1}$, of $33.3 \%$, which is equivalent to a decrease of $4.1 \%$ per unit increase of CEa. [16] and [21] also observed reduction of stomatal conductance in cotton genotypes under salt stress. This behavior was also found for other crops such as castor bean, cowpea, and eggplant [22] [23] [24].

This stomatal closure, due to the application of more salinized water, may be related to the osmotic effect associated with the accumulation of salts in the soil solution, besides the reduction of the hydraulic conductivity of the root system, in accordance with the increase of the suberization and lignification of the tissues of the roots of plants submitted to salinity [25].

In IRGA readings at $30 \mathrm{DAT}$, the mean values obtained by the BRS Verde variety differed statistically from those found for BRS 286 and BRS Topázio, showing higher average gs results.BRS 286 and Topázio did not differ statistically among genotypes, however, BRS Topázio obtained average results of gs slightly higher than those of BRS 286 (Figure 5(b)).

The variables $\mathrm{A}$ and $\mathrm{E}$ had decreasing average results, with the increase of salinity in the substrate, at 15 and 30 DAT, according to the linear regression equation (Figure 6). It may be evidenced by the stomatal closure, which reduces the absorption of atmospheric $\mathrm{CO}_{2}$ and, consequently, the activity of Rubisco and other enzymes, causing negative effects on the carboxylation reactions, important for the accomplishment of the biochemical stage of photosynthesis.

The liquid photosynthesis rate (A) and transpiration (E) decreased by a unit increase of CEa at 15 and 30 DAT, respectively, of $4.2 \%$ and $3.9 \%$, and $7.1 \%$ and $5.9 \%$. Behaviors also found by [24] and [22] in their research.

With the reduction of stomatal conductance, other subsequent processes may be impaired, among them, the decline of liquid photosynthesis, due to the decrease of $\mathrm{CO}_{2}$ partial pressure, in the intercellular spaces or in the substamatic
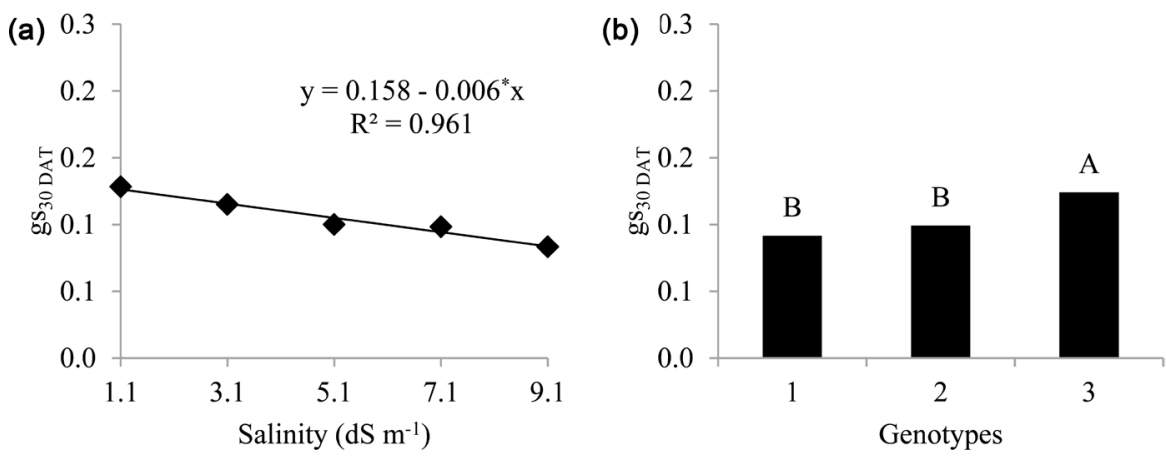

Figures 5. Stomatal conductance (gs) at 30 days DAT, as a function of increasing levels of $\mathrm{CEa}\left(\mathrm{dS} \mathrm{m} \mathrm{m}^{-1}\right)$ and genotypes. Averages with the same letter do not differ significantly from each other. 1-BRS 286; 2-BRS Topázio; 3-BRS Verde. 

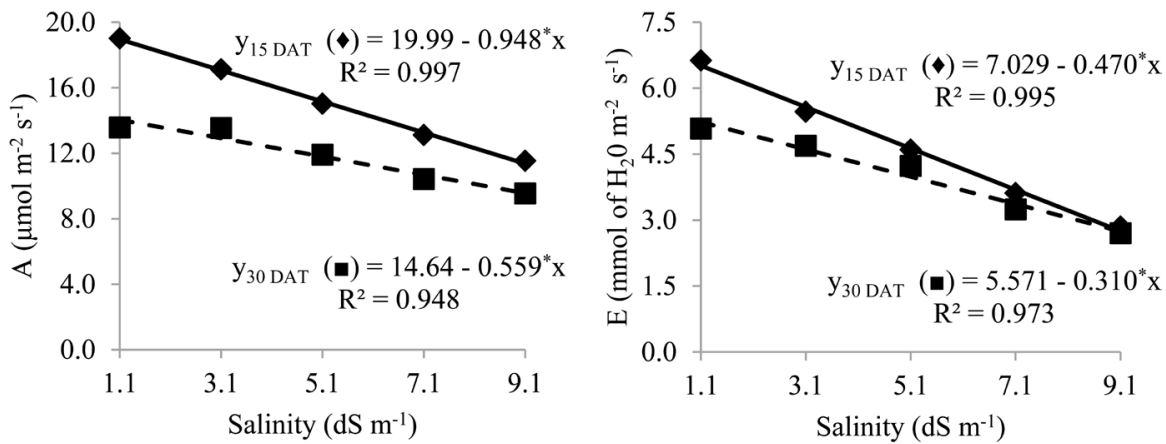

Figure 6. Liquid photosynthesis rate (A) and transpiration (E), at 15 and 30 days DAT, as a function of increasing water salinity levels $\left(\mathrm{dS} \mathrm{m}^{-1}\right)$.

chamber [26]. In addition, stomatal closure restricts the process of transfer of water vapor from the plant to the atmosphere, that is, it reduces the transpiration process [27].

According to [28], the reduction of the growth and development of the crops, in relation to the salt stress, is linked to three factors: stomatal closure, reduction of leaf expansion and acceleration of leaf senescence.

\section{Conclusions}

Increasing CEa levels affected significantly the initial growth and gas exchange of cotton cultivars, both at 15 and 30 DAT.

In general, the white cotton cultivar, BRS 286, showed to be more resistant to the levels of salts analyzed, among the cultivars studied. Among the varieties of colored cotton, BRS Topázio proved to be more resistant to saline stresses, obtaining, in some cases, results similar to cultivar white fiber. BRS Verde was the most sensitive among all evaluated varieties.

\section{Conflicts of Interest}

The authors declare no conflicts of interest regarding the publication of this paper.

\section{References}

[1] Zhu, J.K. (2001) Plant Salt Tolerance. Trends Plant Science, 6, 66-71. https://doi.org/10.1016/S1360-1385(00)01838-0

[2] Feijão, A.R., Silva, J.C.B., Marques, E.C., Prisco, J.T. and Gomes-Filho, E. (2011) Efeito da nutrição de nitrato na tolerância de plantas de sorgo sudão à salinidade. Revista Ciência Agronômica, 42, 675-683. https://doi.org/10.1590/S1806-66902011000300014

[3] Ferrari, E., Paz, A. and Silva, A.C. (2015) Déficit hídrico no metabolismo da soja em semeaduras antecipadas no Mato Grosso. Nativa, 3, 67-77. https://doi.org/10.14583/2318-7670.v03n01a12

[4] Tatagiba, S.D. (2006) Crescimento inicial, trocas gasosas e status hídrico de clones de eucalipto sob diferentes regimes de irrigação. Ph.D. Dissertação, Universidade Federal do Espírito Santo, Espírito Santo. 
[5] Cornic, G. (1994) Drought Stress and High Effects on Leaf Photosynthesis. In: Baker, N.R. and Bowyer, J.R., Eds., Photoinhibition of Photosynthesis, from Molecular Mechanisms to the Field, BIOS Cientific Publishers, Oxford, 297-313.

[6] Echer, F.R., Custódio, C.C., Hosomi, S.T., Dominato, J.C. and Neto, N.B.M. (2010) Estresse hídrico induzido por manitol em cultivares de algodão. Revista Ciência Agronômica, 41, 638-645. https://doi.org/10.1590/S1806-66902010000400018

[7] Ayers, R.S. and Westcot, D.W. (1999) A qualidade da água na agricultura. Universidade Federal da Paraíba, Campina Grande.

[8] Kist, B.B. (2004) Anuário Brasileiro do algodão. Gazeta Santa Cruz, Santa Cruz do Sul.

[9] Novais, R.F., Neves, J.C.L. and Barros, N.F. (1991) Ensaio em ambiente controlado. In: Oliveira, A.J., Garrido, W.E., Araújo, J.D. and Lourenço, S., Coord., Métodos de pesquisa em fertilidade do solo, EMBRAPA, Brasília, Cap. 2, 189-198.

[10] Richards, L.A. (1954) Diagnosis and Improvement of Saline and Alkaline Soils. United States Department of Agriculture, Washington.

[11] Grimes, D.W. and Carter, L.M. (1969) A Linear Rule for Direct Nondestructive Leaf Area Measurements. Agronomy Journal, 61, 477-479. https://doi.org/10.2134/agronj1969.00021962006100030048x

[12] Ferreira, D.F. (2011) Sisvar: A Computer Statistical Analysis System. Ciência e Agrotecnologia, 35, 1039-1042. https://doi.org/10.1590/S1413-70542011000600001

[13] Oliveira, F.A., Medeiros, J.F., Oliveira, R.F.A., Freire, A.G. and Soares, L.C.S. (2012) Produção do algodoeiro em função da salinidade e tratamento de sementes com regulador de crescimento. Revista Ciência Agronômica, 43, 279-287. https://doi.org/10.1590/S1806-66902012000200010

[14] Siqueira, E.C., Gheyi, H.R., Beltrão, N.E.M., Soares, F.A.L., Junior, G.B. and Cavalcanti, M.L.F. (2005) Crescimento do algodão colorido sob diferentes níveis de salinidade da água de irrigação. Revista Brasileira de Engenharia Agrícola e Ambiental, 9, 263-267.

[15] Santos, J. B., Gheyi, H.R., Lima, G.S., Xavier, D.A., Cavalcante, L.F. and Centeno, C.R.M. (2016) Morfofisiologia e produção do algodoeiro herbáceo irrigado com águas salinas e adubado com nitrogênio. Comunicata Scientiae, 7, 86-96. https://doi.org/10.14295/cs.v7i1.1158

[16] Pereira, E.R.L. (2012) Tolerância de genótipos do algodão colorido ao estresse salino. Ph.D. Dissertação, Universidade Estadual da Paraíba, Lagoa Seca, Brasil.

[17] Sousa Jr., S.P., Fernandes, P.D., Gheyi, H.R., Sousa, R.F., Soares, F.A.L., Carvalho, A.P. and Lima, A.N. (2008) Uso de água salina no crescimento do algodoeiro colorido BRS Verde sob adubação nitrogenada. Engenharia Ambiental, 5, 28-46.

[18] Silva, E.N., Silveira, J.A.G., Fernandes, C.R.R., Dutra, A.T.B. and Aragão, R.M. (2009) Acúmulo de íons e crescimento de pinhão-manso sob diferentes níveis de salinidade. Revista de Ciências Agronômicas, 40, 240-246.

[19] Souto, A.G.L., Cavalcante, L.F., Nascimento, J.A.M., Mesquita, F.O. and Neto, A.J.L. (2013) Comportamento do noni à salinidade da água de irrigação em solo com biofertilizante bovino. Irriga, 18, 442-453. https://doi.org/10.15809/irriga.2013v18n3p442

[20] Oliveira, A.M., Oliveira, A.M.P., Dias, N.S. and Medeiros. J.F. (2008) Irrigação com água salina no crescimento inicial de três cultivares de algodão. Irriga, 13, 467-475. https://doi.org/10.15809/irriga.2008v13n4p467-475 
[21] Brito, K.S.A., Fernandes, P.D., Brito, K.Q.D., Suassuna, J.F., Soares, L.A.A. and Nascimento, R. (2014) Trocas gasosas em genótipos de algodoeiro sob estresse salino no segundo ciclo de produção. II Inovagri International Meeting, Fortaleza, Brasil. https://doi.org/10.12702/ii.inovagri.2014-a123

[22] Soares, L.A.A., Nobre, R.G., Gheyi, H.R. and Pereira, F.H.F. (2013) Fisiologia e acúmulo de fitomassa pela mamoneira submetida a estresse salino e adubação nitrogenada. Revista Verde, 8, 247-256.

[23] Prazeres, S.S., Lacerda, C.F., Barbosa, F.E.L., Amorim, A.V., Araujo, I.C.S. and Cavalcante, L.F. (2015) Crescimento e trocas gasosas de plantas de feijão-caupi sob irrigação salina e doses de potássio. Revista Agro@mbiente On-Line, 9, 111-118. https://doi.org/10.18227/1982-8470ragro.v9i2.2161

[24] Bosco, M.R.O., Oliveira, A.B., Hernandez, F.F.F. and Lacerda, C.F. (2009) Efeito do $\mathrm{NaCl}$ sobre o crescimento, fotossíntese e relações hídricas de plantas de berinjela. Revista Ceres, 56, 296-302.

[25] Neves, A.L.R., Lacerda, C.F., Guimarães, F.V.A., Filho, E.G. and Feitosa, D.R.C. (2009) Trocas gasosas e teores de minerais no feijão de corda irrigado com água salina em diferentes estádios. Revista Brasileira de Engenharia Agrícola e Ambiental, 13, 873-881. https://doi.org/10.1590/S1415-43662009000700009

[26] Sultana, N., Ikeda, T. and Itoh, R. (1999) Effect of Salinity on Photosynthesis and Dry Matter Accumulation in Developing Rice Grains. Environmental and Experimental Botany, 42, 211-220. https://doi.org/10.1016/S0098-8472(99)00035-0

[27] Marenco, R.A. and Lopes, N.F. (2005) Fisiologia Vegetal: Fotossíntese, respiração, relações hídricas e nutrição mineral. Universidade Federal de Viçosa, Viçosa, Brasil.

[28] Lacerda, C.F., Cambraia, J., Oliva, M.A., Ruiz, H.A. and Prisco, J.T. (2003) Solute Accumulation and Distribution Shoot and Leaf Development in Two Sorghum Genotypes under Salt Stress. Environmental and Experimental Botany, 49, 107-120. https://doi.org/10.1016/S0098-8472(02)00064-3 